\title{
Chlorophyll profiles and the water column structure in the Gulf of California
}

\section{Raquel M. HIDALGO-GONZÁLEZ*, Saúl ALVAREZ-BORREGO}

División de Oceanología, Centro de Investigación Científica y de Educación Superior de Ensenada, B.C., Km. 107 Carretera Tijuana-Ensenada, Ensenada, Baja California, Mexico

Received 30 May 2000; revised 22 September 2000; accepted 25 October 2000

\begin{abstract}
Remote sensors provide information on the photosynthetic pigment concentration for the upper $22 \%$ of the euphotic zone. To model primary production in the water column from satellite-derived photosynthetic pigments, estimates of the vertical distribution of pigment concentration are required. A Gaussian distribution function is used to represent the pigment vertical profile with four parameters. We used 268 chlorophyll concentration profiles from 1973 through 1993, to estimate these parameters. Cluster analysis of surface temperature was used to define the cool season as the period end of November-end of June, and the rest of the year is considered the warm season. Cluster analysis of surface temperature and chlorophyll data grouped the stations into four regions for the cool season and into two regions for the warm season. Regression models were developed for each region and season to estimate the depth of the deep chlorophyll maximum as a function of the mixed layer depth or an index of stratification. We were not able to generate useful regression models to predict the other three Gaussian parameters. Thus, their representative means were calculated for each region and season. Assuming a homogeneous biomass profile resulted in underestimation of integrated primary production by as much as $60 \%$ with respect to the values derived from the non-homogeneous profiles.
\end{abstract} (C) 2001 Ifremer/CNRS/IRD/Éditions scientifiques et médicales Elsevier SAS

Résumé - Profils de chlorophylle et structure de la colonne d'eau dans le golfe de Californie. La télédétection donne accès à la concentration de pigments photosynthétiques dans les $22 \%$ supérieurs de la couche euphotique. La modélisation de la production primaire dans la colonne d'eau à partir des pigments photosynthétiques dérivés de cette estimation implique des mesures de la distribution verticale de la concentration en pigments. Une fonction de distribution gaussienne a été utilisée pour représenter le profil vertical des pigments avec quatre paramètres. Nous avons utilisé 268 profils de concentrations de chlorophylles, obtenus de 1973 à 1993. L'analyse de nuages de la température superficielle est utilisée pour définir la saison froide (fin novembre - fin juin). Le reste de l'année a été considéré comme la saison chaude. Cette analyse des données de température superficielle et de teneur en chlorophylle met en évidence quatre régions pour la saison froide et deux pour la saison chaude. Les modèles de régression sont développés pour chaque région et pour chaque saison afin d'estimer le maximum profond de chlorophylle en fonction de la profondeur de la couche mélangée ou un indice de stratification. Nous n'avons pas développé de modèle de régression pour la prédiction des trois autres paramètres gaussiens. Aussi, leurs moyennes représentatives ont été calculées pour chaque région et saison. En supposant un profil de biomasse homogène, l'estimation peut conduire une sous-estimation de la production primaire intégrée au plus à $60 \%$, en relation avec des valeurs dérivées de profils non homogènes. (C) 2001 Ifremer/CNRS/IRD/Éditions scientifiques et médicales Elsevier SAS

chlorophyll / vertical profiles / Gulf of California / remote sensing / mixed layer

chlorophylle / profil vertical / golfe de Californie / télédétection / couche mélangée

* Correspondence and reprints.

E-mail addresses: rmaria@cicese (R.M. HIDALGO-GONZÁLEZ), alvarezb@cisese.mx (S. ALVAREZ-BORREGO). 


\section{INTRODUCTION}

Remote sensors provide information on the average photosynthetic pigment concentration for the upper $22 \%$ of the euphotic zone (Kirk, 1994). Empirical and semianalytical algorithms to estimate primary production $(P P)$ from satellite-derived photosynthetic pigments have been compared (Platt and Sathyendranath, 1993; Behrenfeld and Falkowski, 1997). These models apply to the entire euphotic zone, and ideally, they should use the vertical profile of pigment biomass as input (Morel and Berthon, 1989). Therefore a gap exists between the limited satellite pigment information and what is needed when modeling.

The assumption of a mixed layer with a homogeneous pigment distribution could lead to inaccurate estimates of integrated primary production (Platt et al., 1991). The deep chlorophyll maximum $(D C M)$ is a consistent feature in the ocean (Dandonneau, 1979; Cullen and Eppley, 1981). Since the early studies on the $D C M$ an emphasis has been placed on understanding these features (Varela et al., 1992, and references therein). Generally, accounting for its presence increases estimates of integrated production $\left(P P_{\text {int }}\right)$, and since the $D C M$ often appears below the mixed layer, then it would be likely that most of its production is new production (Sathyendranath et al., 1995). Lewis et al. (1983) and Platt et al. (1988) proposed Gaussian distribution functions to represent the vertical profile of chlorophyll concentration $(C h l)$. A difficulty in estimating oceanic production from surface measurements arises from the regional differences in the vertical distribution of chlorophyll. The underlying assumption of a Gaussian distribution function is that for a given region of the ocean, in a given season, the typical shape of the chlorophyll profile is stable. Therefore it is necessary to use chlorophyll historical data to characterize the parameters of the Gaussian function for each oceanic province or region.

Millán-Núñez et al. (1997) used historical CalCOFI data to generate a set of regression models to calculate the Gaussian parameters from chlorophyll surface values, for different regions within the California Current system, and for different seasons. They concluded that within the California Current system assuming a homogeneous biomass profile results in underestimation of integrated production by as much as $30 \%$, whereas their modeled profiles give equal or overestimated integrated production (up to $23 \%$ ), with respect to the values derived from measured profiles.
The Gulf of California is a very dynamic marginal sea of the Pacific Ocean, with high production mainly during winter and spring (Alvarez-Borrego and Lara-Lara, 1991). In the Gulf of California, the DCM coincides with the upper part of the nitracline, where nitrate concentration is $>1.0 \mu \mathrm{M}$ (Cortés-Lara et al., 1999), and this suggests that the DCM may be important as a new production maximum. Also, it has been shown that in the California Current system the DCM provides the necessary dinoflagellate abundance for the survival of first feeding anchovy larvae (Lasker, 1975). The Gulf of California has pelagic fishes of commercial importance like sardine and anchovy. Thus for fisheries oceanographic studies, it would be useful to predict the chlorophyll vertical profiles from satellite color imagery.

The purpose of this work was to empirically relate the Gaussian parameters to properties that may be remotely derived by satellite sensors, such as chlorophyll concentration $\left(C h l_{\text {sat }}\right)$ and temperature $\left(T_{\mathrm{s}}\right)$. Also to relate them to well characterized physical properties, such as the mixed layer depth and an index of stratification, for regions of the Gulf of California. The effect of considering non-homogeneous chlorophyll profiles, versus the homogeneous profiles with the same surface chlorophyll concentration $\left(C h l_{\mathrm{s}}\right)$, on the calculations of primary production was explored. The intention is not to predict chlorophyll profiles to estimate the instantaneous local production, but to provide means to chlorophyll profiles for estimating production for a whole season and a whole region within the Gulf. Morel and Berthon (1989) indicated that it is unreasonable and probably superfluous to envisage the use of a light-production model on a pixel-by-pixel basis when interpreting satellite imagery.

\subsection{Study area}

The Gulf of California is very dynamic because of tidal currents, wind stress, upwelling, and high solar heating. It consists of a series of basins separated by sills. The basins have depths up to $>3000 \mathrm{~m}$ at the entrance region, and they are very shallow in the northern Gulf $(\leq 200 \mathrm{~m})$. Marked seasonal changes of temperature, salinity, currents, and sea level have been reported for the central Gulf of California (Ripa and Marinone, 1989; SotoMardones et al., 1999). However, information about the spatial and temporal variability of chemical and biologi- 
cal processes is scarce. Upwelling occurs off the eastern coast with northwesterly winds ('winter' conditions from December through May), and off the Baja California coast with southeasterly winds ('summer' conditions from July through October), with June and November as transition periods (Alvarez-Borrego and Lara-Lara, 1991). With northwesterly winds, upwelling is strong, it has a marked effect on phytoplankton communities $\left(C h l_{\mathrm{s}}\right.$ values up to more than $10 \mathrm{mg} \mathrm{m}^{-3}$ ), and due to eddy circulation it increases the phytoplankton biomass across the Gulf (Santamaría-Del-Angel et al., 1994). However, because of strong stratification during summer, upwelling with southeasterly winds has a very weak effect on phytoplankton biomass (Santamaría-Del-Angel et al., 1999).

The northern Gulf of California exhibits spectacular tidal phenomena. With amplitude superior to $7 \mathrm{~m}$ during spring tides in the upper Gulf, and superior to $4 \mathrm{~m}$ in the midriff islands area (Tiburón and Angel de la Guarda), tidal energy dissipation rates are great. In the Upper Gulf tidal energy dissipation rates are as large as $>0.5 \mathrm{~W} \mathrm{~m}^{-2}$, and in the midriff islands area they are $>0.3 \mathrm{~W} \mathrm{~m}^{-2}$ (Argote et al., 1995). The lowest surface temperatures of the whole Gulf of California are found here (SotoMardones et al., 1999). Tidal mixing over the sill between San Lorenzo and San Esteban islands produces a vigorous stirring of the water column down to $>500 \mathrm{~m}$ depth (Simpson et al., 1994). Tidal mixing in the midriff islands area causes a net effect of carrying cold and nutrient rich waters to the surface throughout the whole year (AlvarezBorrego, 2000). This produces patches of high Chl (up to $>2 \mathrm{mg} \mathrm{m}^{-3}$ ) in this area even during summer.

\section{DATA AND METHODS}

We used data generated in oceanographic cruises from 1973 through 1993. A cluster analysis of surface temperature was used to define the cool season as the period end of November-end of June, and the rest of the year is considered the warm season. However, to be consistent with the previously defined 'winter' and 'summer' conditions, with November and June as transition periods, and recognizing interannual variability, we followed the criteria in Valdez-Holguín et al. (1999) and considered mean surface temperatures of $<24^{\circ} \mathrm{C}$ as indicative of cool season. Surface temperatures $<24^{\circ} \mathrm{C}$ indicate either strong mixing or the start of upwelling events off the east coast.

Chlorophyll concentration was determined by the standard fluorometric method (Holm-Hansen et al., 1965). Profiles with more than one chlorophyll concentration maximum, and also those with less than four sampled depths, were discarded $(13 \%$, most of them from the southern part of the Gulf). The rest of the chlorophyll profiles (268) were fitted to Platt et al. (1988) equation:

$$
\operatorname{Chl}_{(\mathrm{z})}=\mathrm{Chl}_{\mathrm{o}}+\left[h / \sigma(2 \pi)^{0.5}\right] \exp \left[-\left(Z-Z_{\mathrm{m}}\right)^{2} / 2 \sigma^{2}\right]
$$

where $\mathrm{Chl}_{(\mathrm{z})}$ is the chlorophyll concentration (in milligrams per cubic meter) at depth $Z$ (in meters), $C h l_{\mathrm{o}}$ is the background pigment concentration, $h$ is the total pigment (in milligrams per square meter) above the baseline $C h l_{\mathrm{o}}$, $\sigma$ controls the thickness of the $D C M$ layer, and $Z_{\mathrm{m}}$ is the depth of the chlorophyll concentration maximum. Some examples of $C h l_{(z)}$ profiles with the fitted Gaussian curves are shown in figure 1.
Figure 1. Examples of chlorophyll concentration profiles with the original data points and the representative Gaussian curve: from the cool season (a), and from the warm season (b). Inserted in panel (b) is an idealized deep chlorophyll maximum represented by a Gaussian curve superimposed on a constant background, showing the parameters.

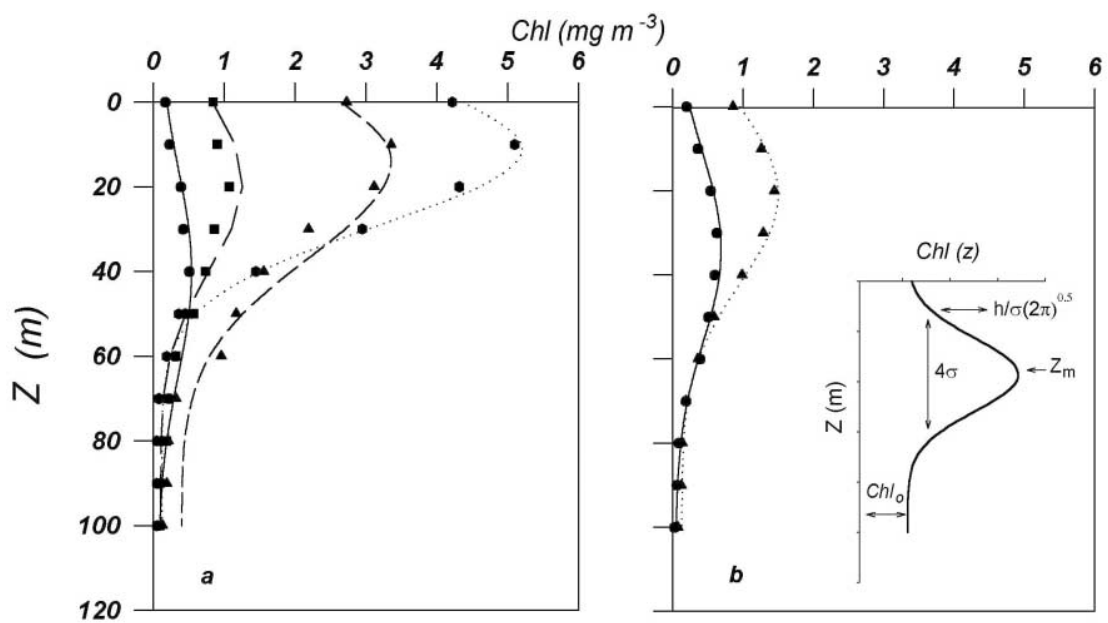


The stratification parameter $\phi_{\mathrm{s}}=(1 / k) \sum_{k}^{0}(\rho-\bar{\rho}) g \cdot z \cdot \Delta z$ was one of the physical variables used to characterize the $D C M$, where $\phi_{\mathrm{s}}$ is the amount of mechanical energy required to bring about vertical mixing (it is zero for a well mixed layer and it increases with stratification), $z$ is the vertical coordinate (positive upwards), $k$ is the depth of integration over the water column $(k=-100 \mathrm{~m}), \rho$ is the water density, $\bar{\rho}$ is the mean $\rho$ for the interval $0-100 \mathrm{~m}, g$ is the acceleration due to gravity, and $\Delta z=1 \mathrm{~m}$ (Simpson and Hunter, 1974). The mixed layer depth (in meters) was calculated following MartínezSepúlveda (1994). The mixed layer was considered to be the portion of the water column where the temperature gradient was $\leq 0.07^{\circ} \mathrm{C} \mathrm{m}^{-1}$ and its bottom was defined as the point where the temperature difference with respect to that of $10 \mathrm{~m}$ depth was $1^{\circ} \mathrm{C}$.

Table I. Numbers of chlorophyll profiles used for each year, month and season for each region.

\begin{tabular}{lrrrrrrr}
\hline & I & II & III & IV & 1 & 2 & Total \\
\hline Year & & & & & & & \\
1973 & 0 & 3 & 25 & 52 & 0 & 0 & 80 \\
1981 & 1 & 0 & & 3 & 0 & 0 & 11 \\
1983 & 5 & 15 & 4 & 0 & 3 & 2 & 29 \\
1984 & 10 & 48 & 14 & 0 & 0 & 0 & 72 \\
1985 & 0 & 17 & 2 & 0 & 9 & 14 & 42 \\
1986 & 0 & 1 & 4 & 3 & 0 & 0 & 8 \\
1990 & 0 & 0 & 0 & 0 & 6 & 13 & 19 \\
1993 & 2 & 2 & 1 & 2 & 0 & 0 & 7 \\
Month & & & & & & & \\
Jan & 0 & 0 & 0 & 0 & 0 & 0 & 0 \\
Feb & 0 & 0 & 14 & 0 & 0 & 0 & 14 \\
Mar & 5 & 34 & 28 & 54 & 0 & 0 & 121 \\
Apr & 12 & 26 & 0 & 0 & 0 & 0 & 38 \\
May & 0 & 0 & 0 & 0 & 0 & 0 & 0 \\
Jun & 0 & 0 & 0 & 0 & 0 & 0 & 0 \\
Jul & 0 & 0 & 0 & 0 & 6 & 13 & 19 \\
Aug & 0 & 0 & 0 & 0 & 0 & 0 & 0 \\
Sept & 0 & 0 & 0 & 0 & 0 & 0 & 0 \\
Oct & 0 & 0 & 2 & 0 & 4 & 13 & 19 \\
Nov & 0 & 16 & 13 & 0 & 8 & 3 & 40 \\
Dec & 1 & 10 & 0 & 6 & 0 & 0 & 17 \\
Season & & & & & & & \\
Cool & 18 & 86 & 56 & 60 & 0 & 0 & 220 \\
Warm & 0 & 0 & 0 & 0 & 18 & 30 & 48 \\
Total & 18 & 86 & 56 & 60 & 18 & 30 & 268 \\
\hline & & & & & & & \\
\hline
\end{tabular}

Numbers on top represent the geographic regions according to figure 3.
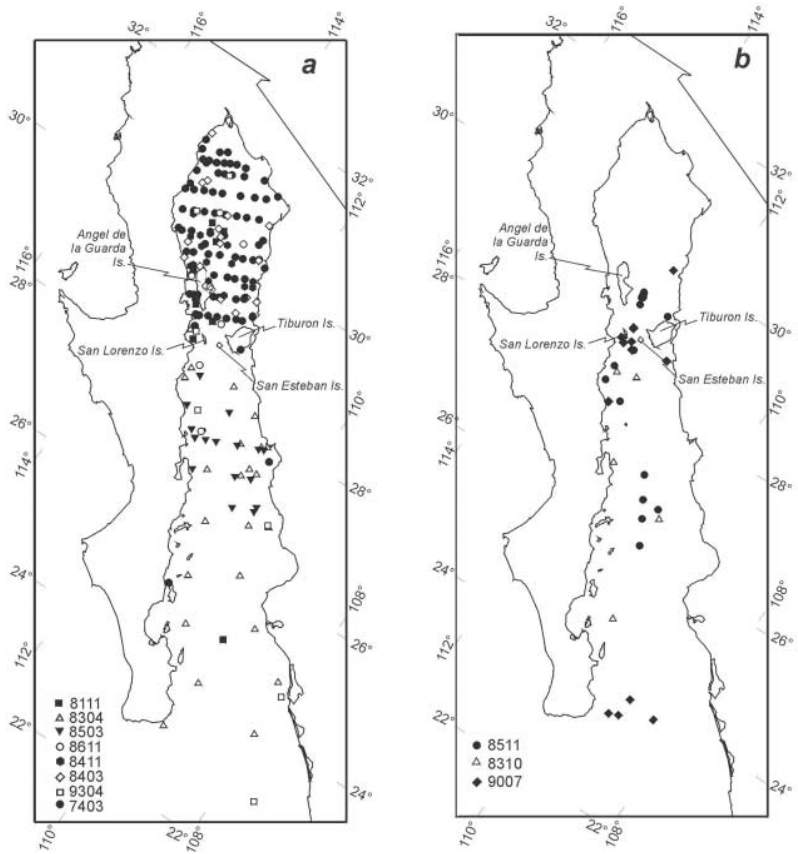

Figure 2. Location of hydrographic stations: cool season (a), and warm season (b). Some hydrographic stations overlap. The first two digits of the numbers by the symbols are the year, and the other two digits are the month.

We tabulated the four Gaussian parameters, $T_{\mathrm{s}}, C h l_{\mathrm{s}}$, chlorophyll at the $D C M\left(C h l_{\mathrm{m}}\right), \phi_{\mathrm{s}}$, and mixed layer depth, for a total of 268 hydrographic stations separated into the two seasons. Table I and figure 2 show the temporal and geographic distributions of these hydrographic stations. A cluster analysis of the cool season $T_{\mathrm{s}}$, $C h l_{\mathrm{s}}, C h l_{\mathrm{m}}$, and $Z_{\mathrm{m}}$ data grouped the stations into four different regions (figure $3 a$ ). The area north from $\sim 31.5^{\circ} \mathrm{N}$ (upper Gulf) is too shallow $(<30 \mathrm{~m})$ and well mixed by tidal currents (Alvarez-Borrego, 2000). The warm season data are less abundant and show less horizontal structure in the Gulf. Only two separate warm season regions ( 1 and 2 ) were recognized by the cluster analysis (figure $3 b$ ). Regression analysis was applied to generate models of $Z_{\mathrm{m}}, h, C h l_{\mathrm{o}}$, and $\sigma$ as functions of $C h l_{\mathrm{s}}, T_{\mathrm{s}}, \phi_{\mathrm{s}}$ and/or mixed layer depth, for each region and season.

Primary production was calculated using the Platt et al. (1991) model to compare the integrated production that results from the modeled chlorophyll profiles versus those resulting from homogeneous chlorophyll distributions. The Platt et al. (1991) expression was used with a 

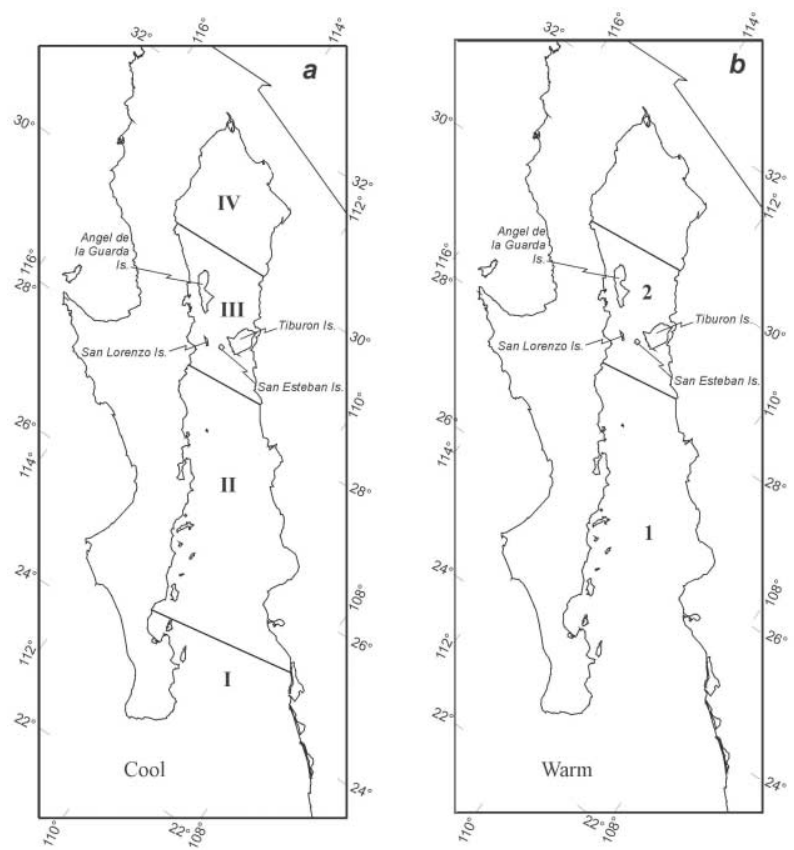

Figure 3. Regions of the Gulf of California for the cool season (a), and for the warm season $(\mathbf{b})$.

modification suggested by Giles-Guzmán and AlvarezBorrego (2000) for case 1 waters. This modification corrects the initial slope $\left(\alpha^{*}{ }_{P A R}\right)$ of the photosynthesis-irradiance relationship ( $P-E$ curves) by the in situ spectral distribution of scalar irradiance $(P A R)$. Instead of the $\alpha^{*}{ }_{P A R}$ expression in Platt et al. (1991), we used $43.2 \phi_{\max } \bar{a}_{p h(z, C h l)}^{*}$ (Giles-Guzmán and Alvarez-Borrego, 2000). The maximum photosynthetic quantum yield at low irradiance ( $\mathrm{mol} C$ ( $^{\mathrm{mol}}$ quanta $)^{-1}$ ) is $\phi_{\max }$. The average specific absorption coefficient of phytoplankton is $\bar{a}_{p h(z, C h l)}$ (in square metres per milligram of chlorophyll), weighted by the in situ spectral distribution of PAR and calculated following Giles-Guzmán and AlvarezBorrego (2000). The factor 43.2 converts milligrams $C$ to moles $\mathrm{C}$, hours to seconds, and micromole quanta to mole quanta. Primary production calculations were performed with mean photosynthetic parameters proposed by Valdez-Holguín et al. (1999) for the whole Gulf of California $\left(\phi_{\max }=0.06 \mathrm{~mol} \mathrm{C}(\mathrm{mol} \mathrm{quanta})^{-1}\right.$; and the assimilation number $\left.\mathrm{P}_{\mathrm{m}}^{*}=9.6 \mathrm{mgC} \mathrm{mgChl}{ }^{-1} \mathrm{~h}^{-1}\right)$. We used constant surface irradiance $\left(E_{P A R \mathrm{o}}=1000 \mu \mathrm{mol}\right.$ quanta $\mathrm{m}^{-2} \mathrm{~s}^{-1}$ ) so that differences could be attributed only to changes of chlorophyll profile.

\section{RESULTS AND DISCUSSION}

The Gulf of California has been divided into regions following different criteria. Our four regions for the cool season coincide very closely with those proposed by Gilbert and Allen (1943) based on the abundance of phytoplankton during winter-spring. Other authors have used phytoplankton remains in the surface sediments (Round, 1967), and the 'winter' physical oceanographic characteristics (Gaxiola-Castro et al., 1995) to arrive to a very similar division of the Gulf into four regions. Santamaría-Del-Angel et al. (1994) used the temporal variation of satellite-derived photosynthetic pigments to propose as many as fourteen regions. These many regions resulted because these latter authors analyzed not only the spatial distribution of pigments but also their fine temporal variation. They generated eight-years time series with weekly composites of coastal zone color scanner data. For the purpose of defining regions to apply primary production models to satellite color data, the larger the regions the better. For example, for the purpose of modeling production, Valdez-Holguín et al. (1999) proposed means of photosynthetic parameters (from $P-E$ curves) for the whole Gulf of California as a single region. Sathyendranath et al. (1995) indicated that most boundaries between biogeochemical regions prove to have some significance for $Z_{\mathrm{m}}$. That is the case for our Gulf of California regions, as will be shown later.

During the cool season, the $T_{\mathrm{s}}$ mean in general decreased from south to north, from $22.6^{\circ} \mathrm{C}$ in region $\mathrm{I}$, to $17.4^{\circ} \mathrm{C}$ in region IV (table II). The means of regions III and IV were not significantly different at the $95 \%$ confidence level. The highest 'winter' $T_{\mathrm{s}}$ means of the four regions for the study period were registered in 1983 (not illustrated) due to the well known ENSO event of that year. During the warm season, the $T_{\mathrm{s}}$ mean decreased a little from region 1 to region 2, from 27.4 to $26.3^{\circ} \mathrm{C}$ (table II). On the other hand, in the cool season, the $C h l_{\mathrm{s}}$ mean values in general increased from $0.2 \mathrm{mg} \mathrm{m}^{-3}$ in region I to $4.2 \mathrm{mg} \mathrm{m}^{-3}$ in region IV (table II). During the warm season, there was a slight tendency for the $C h l_{\mathrm{s}}$ mean to increase from region $1\left(0.4 \mathrm{mg} \mathrm{m}^{-3}\right)$ to region $2\left(0.8 \mathrm{mg} \mathrm{m}^{-3}\right)$ (table II). Mean values of $C h l_{\mathrm{m}}$ varied in a very similar way as those of $C h l_{\mathrm{s}}$ (table II). During the cool season, $C h l_{\mathrm{m}}$ increased from region I to region IV (from 0.6 to $5.8 \mathrm{mg} \mathrm{m}^{-3}$ ). Values of $C h l_{\mathrm{m}}$ for the warm season also increased slightly from region 1 to region 2 ( 0.9 to $1.4 \mathrm{mg} \mathrm{m}^{-3}$ ). 
Table II. Means for each region and season of surface temperature, surface chlorophyll concentration, chlorophyll concentration at the deep chlorophyll maximum, the Gaussian parameters, the mixed layer depth, and the index of stratification.

\begin{tabular}{|c|c|c|c|c|c|c|c|c|c|}
\hline Region & $T_{\mathrm{s}}$ & $C h l_{\mathrm{s}}$ & $C h l_{\mathrm{m}}$ & $h$ & $C h l_{\mathrm{o}}$ & $\sigma \sigma$ & $Z_{\mathrm{m}}$ & MLD & $\phi \phi_{\mathrm{s}}$ \\
\hline I & $22.6 \pm 0.2$ & $0.2 \pm 0.04$ & $0.6 \pm 0.2$ & $30.2 \pm 0.3$ & $0.07 \pm 0.002$ & $25.2 \pm 0.7$ & $36.6 \pm 4.4$ & $27.1 \pm 2.8$ & $52.8 \pm 6.0$ \\
\hline II & $20.5 \pm 0.2$ & $0.9 \pm 0.1$ & $1.3 \pm 0.2$ & $85.4 \pm 0.1$ & $0.1 \pm 0.01$ & $14.6 \pm 0.2$ & $18.7 \pm 1.6$ & $32.2 \pm 1.6$ & $21.6 \pm 3.3$ \\
\hline III & $17.8 \pm 0.2$ & $3.1 \pm 0.3$ & $3.9 \pm 0.4$ & $227.4 \pm 3.9$ & $0.4 \pm 0.01$ & $34.4 \pm 0.3$ & $14.1 \pm 1.6$ & $45.9 \pm 1.9$ & $14.6 \pm 1.8$ \\
\hline IV & $17.4 \pm 0.1$ & $4.2 \pm 0.4$ & $5.9 \pm 0.4$ & $236.0 \pm 1.0$ & $0.1 \pm 0.03$ & $17.5 \pm 0.2$ & $11.3 \pm 1.0$ & $43.1 \pm 1.5$ & $5.7 \pm 0.5$ \\
\hline 1 & $27.4 \pm 0.4$ & $0.4 \pm 0.05$ & $0.9 \pm 0.1$ & $79.4 \pm 5.5$ & $0.1 \pm 0.02$ & $27.4 \pm 1.2$ & $28.3 \pm 2.5$ & $24.8 \pm 1.1$ & $175.2 \pm 2.1$ \\
\hline 2 & $26.3 \pm 0.4$ & $0.8 \pm 0.2$ & $1.4 \pm 0.2$ & $167.1 \pm 12.4$ & $0.3 \pm 0.03$ & $24.2 \pm 1.9$ & $19.8 \pm 3.2$ & $29.9 \pm 1.6$ & $103.6 \pm 3.1$ \\
\hline
\end{tabular}

Values are mean \pm standard error: $T_{\mathrm{s}}$ in degrees, $C h l_{\mathrm{s}}$ and $C h l_{\mathrm{m}}$ in milligrams per cubic meter, $M L D$ in meters, $\phi_{\mathrm{s}}$ in Joules per cubic meter. Numbers on the left column represent the regions and seasons.

An important limitation of our study is that our data are discrete, based on water samples from bottles. Continuous flow in vivo fluorometry made possible the observation that phytoplankton could be concentrated in layers easily missed by conventional sampling schemes (Strickland, 1968). Vertical movements of these layers have been observed (Gieskes et al., 1978). Unfortunately, there are no available reports of continuous flow fluorometry from the Gulf of California. Presently, the use of HPLC chlorophyll data provides better estimates than those of fluorometric analysis. Nevertheless, Trees et al. (2000) reported that there is a strong linear relationship for $\log$ accessory pigments versus log chlorophyll, and this largely explains the success in remotely sensed chlorophyll, even though phytoplankton populations can vary in their composition and suite of pigments.

During both seasons, $h$ significantly increased from south to north (table II). Lowest $h$ mean value was $30 \mathrm{mg} \mathrm{m}^{-2}$, for region $I$, and highest value was $236 \mathrm{mg} \mathrm{m}^{-2}$, for region IV (table II). Values for the parameter $h$ are higher than integrated chlorophyll for the euphotic zone because $h$ values include the whole area under the Gaussian curve. Regions II and IV had very different $h$ values with very similar $\sigma$ and $C h l_{\mathrm{o}}$ values due to different $C h l_{\mathrm{m}}$ values. In the cool season, $C h l_{\mathrm{o}}$ increased slightly from region I to region II $\left(0.07\right.$ to $\left.0.11 \mathrm{mg} \mathrm{m}^{-3}\right)$, then it had a relatively high value in region III $\left(0.39 \mathrm{mg} \mathrm{m}^{-3}\right)$ and decreased in region IV to a value similar to that of region II $\left(0.14 \mathrm{mg} \mathrm{m}^{-3}\right)$. In the warm season, $C h l_{\mathrm{o}}$ increased northward (table II). The mean of $\sigma$ did not have a monotonic pattern of geographic change in the cool season. Its range was 14.6 to $34.4 \mathrm{~m}$. During the warm season, $\sigma$ had values similar to that for region I, with no significant difference between regions 1 and 2 (table II). Relatively few of the profiles $(\sim 15 \%)$ had surface maxima $\left(Z_{\mathrm{m}}=\right.$ $0 \mathrm{~m}$ ), and none of these were in regions I and 1 . The mean depth of the DCM, $Z_{\mathrm{m}}$, showed a clear tendency to decrease from south to north in the cool season (from 36.6 to $11.3 \mathrm{~m}$ ), but this tendency was not as strong in the warm season ( 28.3 to $19.8 \mathrm{~m}$ ) (table II).

As expected, the mean mixed layer depth and the mean index of stratification, $\phi_{\mathrm{s}}$, had opposite behaviors. The mean mixed layer depth in general increased from south to north, and it was larger for the cool season than for the warm season. Its values for regions I and II were not significantly different, and neither were those for regions III and IV. The mean $\phi_{\mathrm{s}}$ in general decreased from south to north, and it was larger for the warm season than for the cool season. Maximum $\phi_{\mathrm{s}}$ mean value was $175 \mathrm{~J} \mathrm{~m}^{-3}$, for region 1 , and the minimum was $6 \mathrm{~J} \mathrm{~m}^{-3}$ for region IV.

Simple linear regression models for the Gaussian parameters as functions of $C h l_{\mathrm{s}}, T_{\mathrm{s}}$, mixed layer depth, or $\phi_{\mathrm{s}}$ were not significant, with the exception of those for $Z_{\mathrm{m}}$. The depth of the chlorophyll maximum, $Z_{\mathrm{m}}$, had a significant correlation only with mixed layer depth and with $\phi_{\mathrm{s}}$ (table III, figures 4, 5). In some cases, graphs of the Gaussian parameters versus one of the independent variables suggested a linear relationship, and in other cases they showed an exponential relationship (not illustrated). Simple regression of $\ln$ of the parameters versus $\ln$ of the independent variables did not yield significant results in the cases of $C h l_{\mathrm{o}}, h$, and $\sigma$, and in the case of $Z_{\mathrm{m}}$ it did not provide better results than the linear models. The addition of a second independent variable to the models did not contribute significantly to improving the correlation coefficient $(r)$ at the $95 \%$ confidence level.

With more than 3000 chlorophyll profiles, Millán-Núñez et al. (1997) were not able to build predictive models for 
Table III. Regression equations to estimate $Z_{\mathrm{m}}$ as function of either the mixed layer depth $(M L D)$ or the index of stratification $\left(\phi_{\mathrm{s}}\right)$, for each region and season.

\begin{tabular}{llllll}
\hline Region & Cool & & Region & Warm \\
\hline I & $Z_{\mathrm{m}}=78-1.55 \times M L D$ & $r^{2}=0.94$ & 1 & $Z_{\mathrm{m}}=68-1.5 \times M L D$ & $r^{2}=0.97$ \\
& $Z_{\mathrm{m}}=0.4+0.7 \phi_{\mathrm{s}}$ & $r^{2}=0.90$ & & $Z_{\mathrm{m}}=-112.5+0.8 \phi \phi_{\mathrm{s}}$ & $r^{2}=0.94$ \\
II & $Z_{\mathrm{m}}=68-1.5 \times M L D$ & $r^{2}=0.94$ & & & \\
& $Z_{\mathrm{m}}=0.2+0.84 \phi_{\mathrm{s}}$ & $r^{2}=0.92$ & & & $r^{2}=0.93$ \\
III & $Z_{\mathrm{m}}=50.5-0.79 \times M L D$ & $r^{2}=0.88$ & 2 & $Z_{\mathrm{m}}=69.1-1.9 \times M L D$ & $r^{2}=0.95$ \\
& $Z_{\mathrm{m}}=0.2+0.96 \phi_{\mathrm{s}}$ & $r^{2}=0.94$ & & $Z_{\mathrm{m}}=-84.4+1.0 \phi_{\mathrm{s}}$ & \\
IV & $Z_{\mathrm{m}}=40.2-0.65 \times M L D$ & $r^{2}=0.88$ & & & \\
& $Z_{\mathrm{m}}=-0.7+2.17 \phi_{\mathrm{s}}$ & $r^{2}=0.93$ & & & \\
\end{tabular}

$\sigma$, for most regions within the California Current system; and in some cases they could not build models for $\mathrm{Chl}_{\mathrm{o}}$. Sathyendranath et al. (1995) concluded that prediction of $\sigma$ from $\mathrm{Chl}_{\mathrm{s}}$, or from other variables, is impracticable. Millán-Núñez et al. (1997) indicated that in those cases where the regressions were not significant, the means of the parameters for the corresponding region and season are to be used. Due to the scarcity of data from the Gulf of California we were not able to find any significant correlation between the Gaussian parameters and surface properties that can be remotely derived by satellite
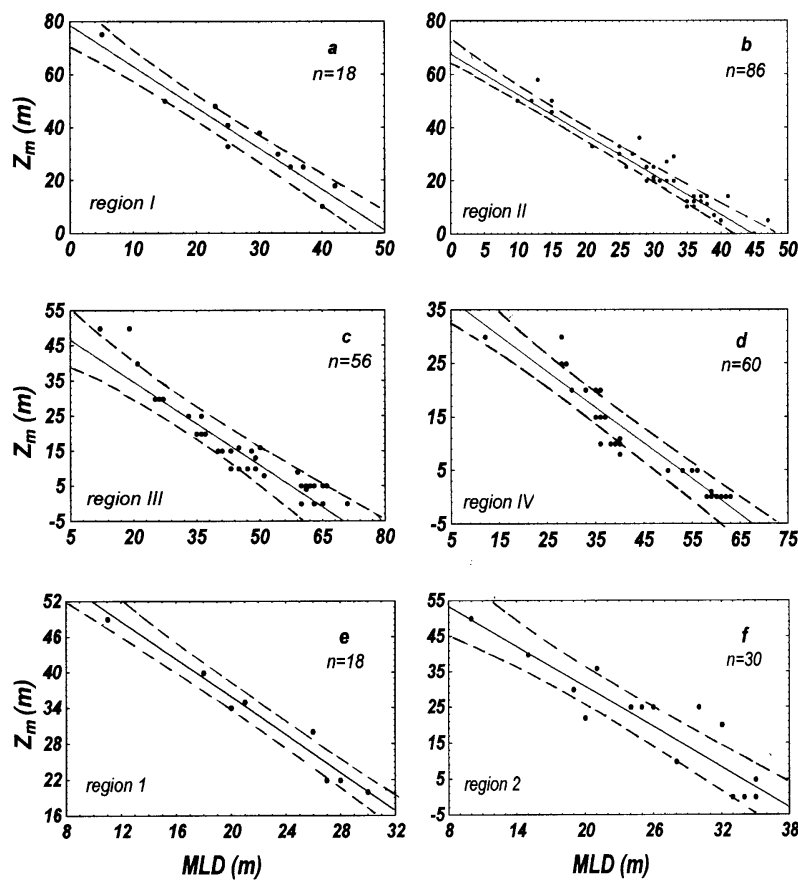

Figure 4. Regression lines for $Z_{\mathrm{m}}$ as a function of the mixed layer depth $(M L D)$. Dashed lines are the $95 \%$ confidence envelopes. Many data points overlap. For equations see table III. sensors. Thus, we propose to use means of $C h l_{\mathrm{o}}, h$, and $\sigma$, for each region and season (table II), to calculate the representative $\mathrm{Chl}_{(z)}$ profile.

The depth of the $D C M, Z_{\mathrm{m}}$, changes inversely with the mixed layer depth and directly with $\phi_{\mathrm{s}}$, so that largest $\phi_{\mathrm{s}}$ values correspond to largest $Z_{\mathrm{m}}$ values, and vice versa (the more stratified the water column the deeper the $D C M$ ) (figures 4, 5). Equations in table III show a clear relation between the physical structure of the water column and the $C h l_{(z)}$ profiles in the Gulf of California.
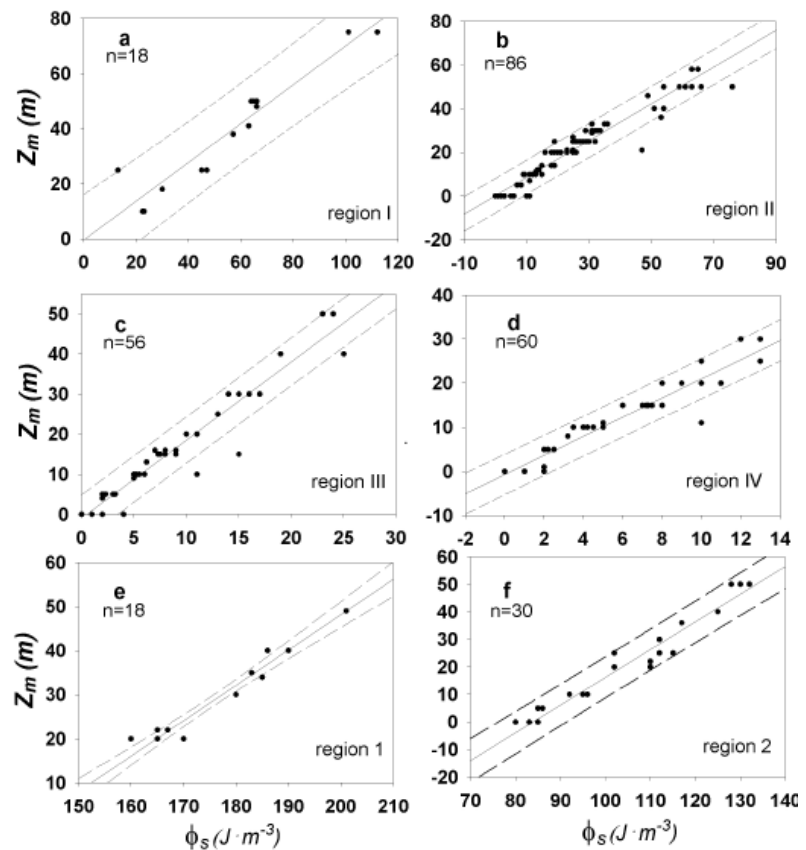

Figure 5. Regression lines for $Z_{\mathrm{m}}$ as a function of the index of stratification $\left(\phi_{\mathrm{s}}\right)$. Dashed lines are the $95 \%$ confidence envelopes. Many data points overlap. For equations see table III. 

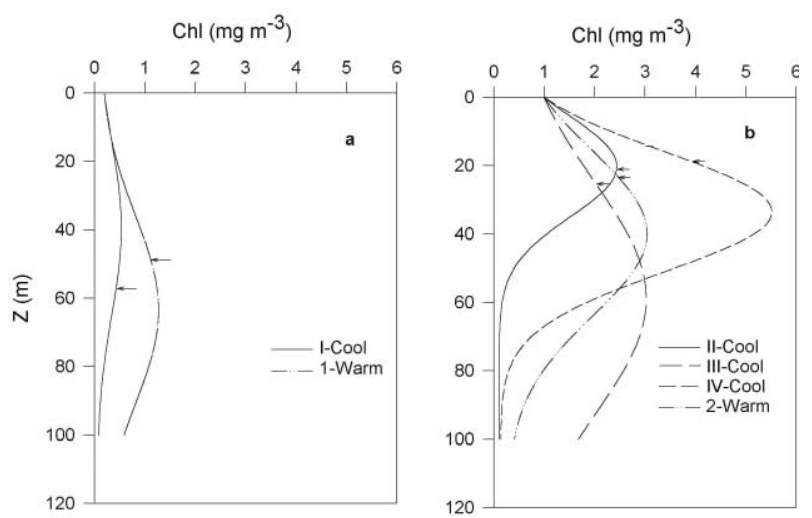

Figure 6. Examples of profiles estimated with the same surface chlorophyll concentration $\left(C h l_{\mathrm{s}}\right)$ value for different regions and seasons: $C h l_{\mathrm{s}}=0.2 \mathrm{mg} \cdot \mathrm{m}^{-3}$ (left panel) and $C h l_{\mathrm{s}}=1.0 \mathrm{mg} \cdot \mathrm{m}^{-3}$ (right panel). Horizontal arrows indicate the bottom of the euphotic zone $(1 \%$ $E_{\mathrm{o}}$ light level).

For the purpose of predicting the $C h l_{(z)}$ profiles, we have three alternatives to estimate $Z_{\mathrm{m}}$. One is to use the regression equations in table III to calculate $Z_{\mathrm{m}}$ as a function of either mixed layer depth or $\phi_{\mathrm{s}}$. Unfortunately this is not practical, because remotely sensed variables, such as $T_{\mathrm{s}}$, do not readily provide estimates of mixed layer depth or $\phi_{\mathrm{s}}$. These parameters have a low correlation with $T_{\mathrm{s}}$. The detailed description of the spatial and temporal variation of mixed layer depth and $\phi_{\mathrm{s}}$, and the development of algorithms to calculate them for the Gulf of California from variables such as $T_{\mathrm{s}}$ are beyond the scope of this contribution. The second alternative is to use the mean of $Z_{\mathrm{m}}$ for each region and season, but this leaves no degrees of freedom for the use of satellite imagery. Thus, once the means of $C h l_{\mathrm{o}}, h$, and $\sigma$, for a region and season are determined (table II), the third alternative to estimate $Z_{\mathrm{m}}$ is to use equation 1 and the mean value of the chlorophyll concentration from the satellite composite image $\left(C h l_{\text {sat }}\right)$, for that region and season of the particular year. As a first approximation, we can represent $C h l_{\text {sat }}$ by the average of $C h l_{(z)}$ for the first optical depth, weighted by the irradiance attenuated twice (when the light is going down and when it is backscattered up) (Kirk, 1994). For our Gulf of California data set, $\mathrm{Chl}_{\text {sat }}$ is about $10 \%$ higher than the surface value $C h l_{\mathrm{s}}$. Thus:

$$
\begin{gathered}
C h l_{\mathrm{s}}=0.9 \operatorname{Chl}_{\mathrm{sat}}=C h l_{\mathrm{o}}+\left[h / \sigma(2 \pi)^{0.5}\right] \exp \left[-Z_{\mathrm{m}}^{2} / 2 \sigma^{2}\right],(2) \\
h /\left[\sigma(2 \pi)^{0.5}\left(0.9 C h l_{\mathrm{sat}}-C h l_{\mathrm{o}}\right)\right]=\exp \left[Z_{\mathrm{m}}^{2} / 2 \sigma^{2}\right], \\
Z_{\mathrm{m}}=\sigma\left\{2 \ln \left[h /\left(\sigma(2 \pi)^{0.5}\left(0.9 C h l_{\mathrm{sat}}-C h l_{\mathrm{o}}\right)\right)\right]\right\}^{0.5}
\end{gathered}
$$

The $Z_{\mathrm{m}}$ values derived from equation 2 are practically the same as those derived directly from the chlorophyll profiles. A single $C h l_{\mathrm{s}}$ value produces different $C h l_{(z)}$ profiles for the different regions and seasons. As examples we calculated the profiles with $C h l_{\mathrm{s}}$ equal to $0.2 \mathrm{mg} \mathrm{m}^{-3}$ and $1.0 \mathrm{mg} \mathrm{m}^{-3}$ (figure $6 a, b$ ). No biomass profiles were generated for regions II, III, IV, and 2 for $C h l_{\mathrm{s}}=0.2 \mathrm{mg} \mathrm{m}^{-3}$ (figure $6 a$ ), because they did not present such a low $C h l_{\mathrm{s}}$ mean in the period 1973-1993. And no biomass profiles were generated for regions I and 1 for $C h l_{\mathrm{s}}=1.0 \mathrm{mg} \mathrm{m}^{-3}$ (figure $6 b$ ), because they did not present such a high $C h l_{\mathrm{s}}$ mean for that period. In all cases, there is a clear change of profile shape depending on the region and season. The procedure proposed by Giles-Guzmán and Alvarez-Borrego (2000) was used to estimate the coefficient of vertical attenuation of difused light for case I waters $\left(\mathrm{Chl}<1.5 \mathrm{mg} \mathrm{m}^{-3}\right)$, and that of Barnard et al. (1999) was used for waters with $C h l>1.5 \mathrm{mg} \mathrm{m}^{-3}$. Integrated chlorophll and primary production from the Gaussian profiles were higher than those obtained from the homogeneous distributions (table IV). Sathyendranath et al. (1995) found that at the scale of individual provinces, the nonuniform production result was always equal to or higher than the uniform one. Assuming a homogeneous biomass profile resulted in underestimation of integrated primary production by as much as $60 \%$ and $26 \%$ with respect to the values derived from the non-homogeneous profiles, for the low and the high $C h l_{\mathrm{s}}$ examples, respectively. A similar result was reported by Millán-Núñez et al. (1997) for the California Current system.

We can use the results in table $I V$ to analyze whether Gaussian biomass profiles derived for different regions and seasons, and with the same $C h l_{\mathrm{s}}$, produce different integrated production values. Integrated production presents larger differences between seasons at the low than at the high $C h l_{\mathrm{s}}$ example. With $C h l_{\mathrm{s}}=0.2 \mathrm{mg} \mathrm{m}^{-3}$, integrated production for region 1 is about $18 \%$ larger than that for region I. With $C h l_{\mathrm{s}}=1.0 \mathrm{mg} \mathrm{m}^{-3}$, integrated production for regions II, III, and 2 had practically the same value, and that for region IV was only about $10 \%$ higher. Thus, with high $C h l_{\mathrm{s}}$ values there is no significant integrated production difference between seasons and regions. Nevertheless, $Z_{\mathrm{m}}$ and chlorophyll concentration at the $D C M\left(C h l_{\mathrm{m}}\right)$ show large changes between regions and seasons (figure $6 a$ and $b$ ) and this may be important for fisheries studies. 
Table IV. Examples of integrated chlorophyll and primary production from our model and for homogeneous biomass distributions $\left(H C h l_{\text {int }}, H P P_{\text {int }}\right)$, for each region and season.

\begin{tabular}{|c|c|c|c|c|c|c|c|c|}
\hline \multirow[b]{2}{*}{ Region } & \multicolumn{4}{|c|}{$C h l=0.2 \mathrm{mg} \mathrm{m}^{-3}$} & \multicolumn{4}{|c|}{$C h l=1.0 \mathrm{mg} \mathrm{m}^{-3}$} \\
\hline & $C h l_{\text {int }}$ & $P P_{\text {int }}$ & $H C h l_{\text {int }}$ & $H P P_{\text {int }}$ & $C h l_{\text {int }}$ & $P P_{\text {int }}$ & $H C h l_{\text {int }}$ & $H P P_{\text {int }}$ \\
\hline I & 24.8 & 54.7 & 16.8 & 25.9 & - & - & - & - \\
\hline II & - & - & - & - & 41.4 & 174.4 & 35 & 143.2 \\
\hline III & - & - & - & - & 40.4 & 174.0 & 35 & 143.2 \\
\hline IV & - & - & - & - & 46.6 & 192.6 & 35 & 143.2 \\
\hline 1 & 28.5 & 64.5 & 16.8 & 25.9 & - & - & - & - \\
\hline 2 & - & - & - & - & 40.7 & 175.5 & 35 & 143.2 \\
\hline
\end{tabular}

$C h l_{\text {int }}$ in milligrams per square meter, $P P_{\text {int }}$ in milligramC per square meter per hour.

In conclusion, the capability to associate nonhomogeneous chlorophyll profiles to data from satellite color sensors allows us to improve the estimates of primary production. Assuming a homogeneous biomass profile for the Gulf of California may result in significant underestimation of integrated primary production. In the Gulf of California the vertical distribution of the phytoplankton biomass is strongly correlated with the structure of the water column. The division of the Gulf of California into regions only give significant differences in the primary production estimates for cases where surface chlorophyll concentrations are relatively low (i.e., $0.2 \mathrm{mg} \mathrm{m}^{-3}$ ). However, $Z_{\mathrm{m}}$ and chlorophyll concentration at the $D C M$ show large changes between regions and seasons even for large surface chlorophyll values and this may be important for fisheries studies.

\section{Acknowledgements}

J.M. Domínguez and F. Ponce did the art work. We thank an anonymous reviewer for his (her) constructive comments to the original version of this contribution.

\section{REFERENCES}

Alvarez-Borrego, S., Lara-Lara, J.R., 1991. The physical environment and primary productivity of the Gulf of California. In: Dauphin, J.P., Simoneit, B.R. (Eds.), The Gulf of California and peninsular province of the Californias, Memoir 47. American Association of Petroleum Geologists, Tulsa, OK, pp. 555-567.

Alvarez-Borrego, S., 2000. Physical Oceanography. In: Case, T.J., Cody, M.L., Ezcurra, E. (Eds.), Island biogeography in the Sea of Cortez. Oxford University Press, New York.
Argote, M.L., Amador, A., Lavin, M.F., Hunter, J.R., 1995. Tidal dissipation and stratification in the Gulf of California. J. Geophys. Res. 100, 16103-16118.

Barnard, A.H., Zaneveld, J.R.V., Pegau, W.S., Mueller, J.L., Maske, H., Lara-Lara, J.R., Alvarez-Borrego, S., Cervantes-Duarte, R., ValdezHolguín, J.E., 1999. The determination of PAR levels from absorption coefficient profiles at $490 \mathrm{~nm}$. Cienc. Mar. 25, 487-507.

Behrenfeld, M.J., Falkowski, P.G., 1997. A consumer's guide to phytoplankton primary productivity models. Limnol. Oceanogr. 42, 1479-1491.

Cortés-Lara, M.C., Alvarez-Borrego, S., Giles-Guzmán, A.D., 1999. Efecto de la mezcla vertical sobre la distribución de nutrientes y fitoplancton en dos regiones del Golfo de California, en verano (in Spanish). Rev. Mex. Hist. Nat. 49, 193-206.

Cullen, J.J., Eppley, R.W., 1981. Chlorophyll maximum layers of the Southern California Bight and possible mechanisms of their formation and maintenance. Oceanol. Acta 4, 23-32.

Dandonneau, Y., 1979. Concentrations en chlorophylle dans le Pacifique tropical sud-ouest: comparaison avec d'autres aires océaniques tropicales. Oceanol. Acta 2, 133-142.

Gaxiola-Castro, G., García-Córdoba, J., Valdez-Holguín, J.E., BotelloRuvalcaba, M., 1995. Spatial distribution of chlorophyll $a$ and primary productivity in relation to winter physical structure in the Gulf of California. Continental Shelf Res. 15, 1043-1059.

Giles-Guzmán, A.D., Alvarez-Borrego, S., 2000. Vertical attenuation coefficient of photosynthetically active radiation as a function of chlorophyll concentration and depth in case 1 waters. Appl. Opt. 39, 1351-1358.

Gieskes, W.W.G., Kraay, G.W., Tijseen, S.B., 1978. Chlorophylls and their degradation products in the deep pigment maximum layer of the tropical North Atlantic. Neth. J. Sea Res. 12, 195-204.

Holm-Hansen, O., Lorenzen, C.J., Holmes, R.W., Strickland, J.D.H., 1965. Fluorometric determination of chlorophyll. J. Cons. Perm. Int. Explor. Mer 30, 3-15.

Kirk, J.T.O., 1994. Light and photosynthesis in aquatic ecosystems. Cambridge University Press, New York.

Lasker, R., 1975. Field criteria for the survival of anchovy larvae: The relation between inshore chlorophyll maximum layers and successful first feeding. Fish. Bull. 73, 847-855. 
Lewis, M.R., Cullen, J.J., Platt, T., 1983. Phytoplankton and thermal structure in the upper ocean: Consequences of nonuniformity in chlorophyll profile. J. Geophys. Res. 88, 2565-2570.

Martínez-Sepúlveda, M., 1994. Descripción de la profundidad de la capa mezclada superficial en el Golfo de California (in Spanish), B.S. Thesis. University of Baja California, Ensenada.

Millán-Núñez, R., Alvarez-Borrego, S., Trees, C.C., 1997. Modeling the vertical distribution of chlorophyll in the California Current System. J. Geophys. Res. 102, 8587-8595.

Morel, A., Berthon, J.F., 1989. Surface pigments, algal biomass profiles, and potential production of the euphotic layer: Relationships reinvestigated in view of remote-sensing applications. Limnol. Oceanogr. 34, 1545-1562.

Platt, T., Sathyendranath, S., Caverhill, C.M., Lewis, M.R., 1988. Ocean primary production and available light: Further algorithms for remote sensing. Deep-Sea Res. 35, 855-879.

Platt, T., Caverhill, C.M., Sathyendranath, S., 1991. Basin-scale estimates of oceanic primary production by remote sensing: the North Atlantic. J. Geophys. Res. 96, 15147-15159.

Platt, T., Sathyendranath, S., 1993. Estimators of primary production for interpretation of remotely sensed data on ocean color. J. Geophys. Res. 98, 14561-14576.

Ripa, P., Marinone, S.G., 1989. Seasonal variability of temperature, salinity, velocity, vorticity and sea level in the central Gulf of California, as inferred from historical data. Quaternary J. Royal Meteorol. Soc. 115, 887-913.

Round, F.E., 1967. The phytoplankton of the Gulf of California - Part I. Its composition, distribution and contribution to the sediments. J. Exper. Mar. Biol. Ecol. 1, 76-97.

Santamaría-Del-Angel, E., Alvarez-Borrego, S., Muller-Karger, F.E., 1994. Gulf of California biogeographic regions based on coastal zone color scanner imagery. J. Geophys. Res. 99, 7411-7421.
Santamaría-Del-Angel, E., Alvarez-Borrego, S., Millán-Nuñez, R., Muller-Karger, F.E., 1999. Sobre el efecto de las surgencias de verano en la biomasa fitoplanctónica del Golfo de California (in Spanish). Rev. Soc. Mex. Hist. Nat. 49, 207-212.

Sathyendranath, S., Longhurst, A., Caverhill, C.M., Platt, T., 1995. Regionally and seasonally differentiated primary production in the North Atlantic. Deep-Sea Res. 42, 1773-1802.

Simpson, J.H., Hunter, J.R., 1974. Fronts in the Irish Sea. Nature 250, 404-406.

Simpson, J.H., Souza, A.J., Lavin, M.F., 1994. Tidal mixing in the Gulf of California. In: Beven, K.J., Chatwin, P.C., Millbank, J.H. (Eds.), Mixing and transport in the environment. John Wiley and Sons Ltd, London, pp. 169-182.

Soto-Mardones, L., Marinone, S.G., Parés-Sierra, A., 1999. Time and spatial variability of sea surface temperature in the Gulf of California. Cienc. Mar. 25, 1-30.

Strickland, J.D.H., 1968. A comparison of profiles of nutrient and chlorophyll concentrations taken from discrete depths and by continuous recording. Limnol. Oceanogr. 13, 388-391.

Trees, C.C., Clark, D.K., Bidigare, R.R., Ondrusek, M.E., Mueller, J.L., 2000. Accessory pigments versus chlorophyll $a$ concentrations within the euphotic zone: a ubiquitous relationship. Limnol. Oceanogr. 45, 1130-1143.

Valdez-Holguín, J.E., Alvarez-Borrego, S., Trees, C.C., 1999. Seasonal and spatial characterization of the Gulf of California phytoplankton photosynthetic parameters. Cienc. Mar. 25, 445-467.

Varela, R.A., Cruzado, A., Tintoré, J., García Landona, E., 1992. Modeling the deep chlorophyll maximum: a coupled physicalbiological approach. J. Mar. Res. 50, 441-463. 